\title{
CORRELATIONS BETWEEN THE AIR POLLUTION AND THE RAINFALL COMPOSITION IN JIULUI VALLEY AREA
}

\author{
TRAISTĂ EUGEN ${ }^{1}$, IONICĂ MĂDĂLINA, CODREA VLAD² ${ }^{2}$, BARBU OVIDIU
}

\begin{abstract}
Rainfall composition is conditional on the air quality. If the air is polluted the rainfall will be also polluted. In fact, rainfall contains the same compounds like the air as nitrites, nitrates, sulphites, sulphates, ammonia etc. Some cations like calcium, magnesium, sodium and potassium are present in rainfall because of dust. This paper presents the air qualities and the soil composition influenced by the rainfall in one of the most polluted mining areas from our country, Jiului Valley.
\end{abstract}

Key words: Air, soil and water pollution; Jiului Valley; Romania.

\section{INTRODUCTION}

The air pollution refers to the presence into the atmosphere of several substances that in some concentrations and/or time of action engender health modifications, low amenity or lead to the environment deterioration.

These substances can be different from the ones normally existing in the air composition, or can be usual components of the air as ozone, carbon dioxide, azote oxides or radon. The atmosphere cannot be considered polluted if these substances from the air do not induce harmfulness effects against the humans or the environment.

Overflowing the nature's self defense limits, i.e. regrowth and dynamic balancing, all the new pollutants are rapidly spreading into the air, water or soil, generating harmful effects (Traistă \& Madear, 2000).

Jiului Valley represents a very illustrating area infested by the air pollution due to the industrial activities. The dust is generated mainly by the thermoelectric power plants' works, as well as by the coal mining fields. These dusts are spread on preferential directions by the winds dominantly blowing from SE/NW and NE/SW (Rebrişoreanu et al., 2002). Beginning from these dusts, the rainfall from the area became polluted too.

The Jiu Valley is located in the Petroşani Depression that represents the heritage of a post-Laramie basin filled with Paleogene and Lower Miocene molass sediments (Pop, 1993) bearing several coal strata. The majority of coal beds is Late Oligocene (Chattian) and belongs to Dâlja-Uricani Formation (Moisescu, 1980). The coal is mined in some major coalfields. Even if these activities decreased in the last decade, they still remain important for the country's economy.

\footnotetext{
${ }^{1}$ Petroşani University, 20 Universității Str., Petroşani

2 Babeş-Bolyai University, 1 Kogălniceanu Str., Dept. of Geology, 400084 Cluj-Napoca.

E-mail:vcodrea@bioge.ubbcluj.ro
} 
From a geographical viewpoint, the Petroşani Depression represents a close area, surrounded by some mountains that belong to the South Carpathians: Parâng and Vâlcan toward the South, and Retezat and Şurianu toward the North. As a whole, the depression has an allonged triangular outline, with its base toward the East. Petroşani, the main town from the area, is located toward the depression's Eastern side. The main water streams draining the depression are the East and West Jiu valleys, the last one being considerably longer if related to the first (Fig. 1).

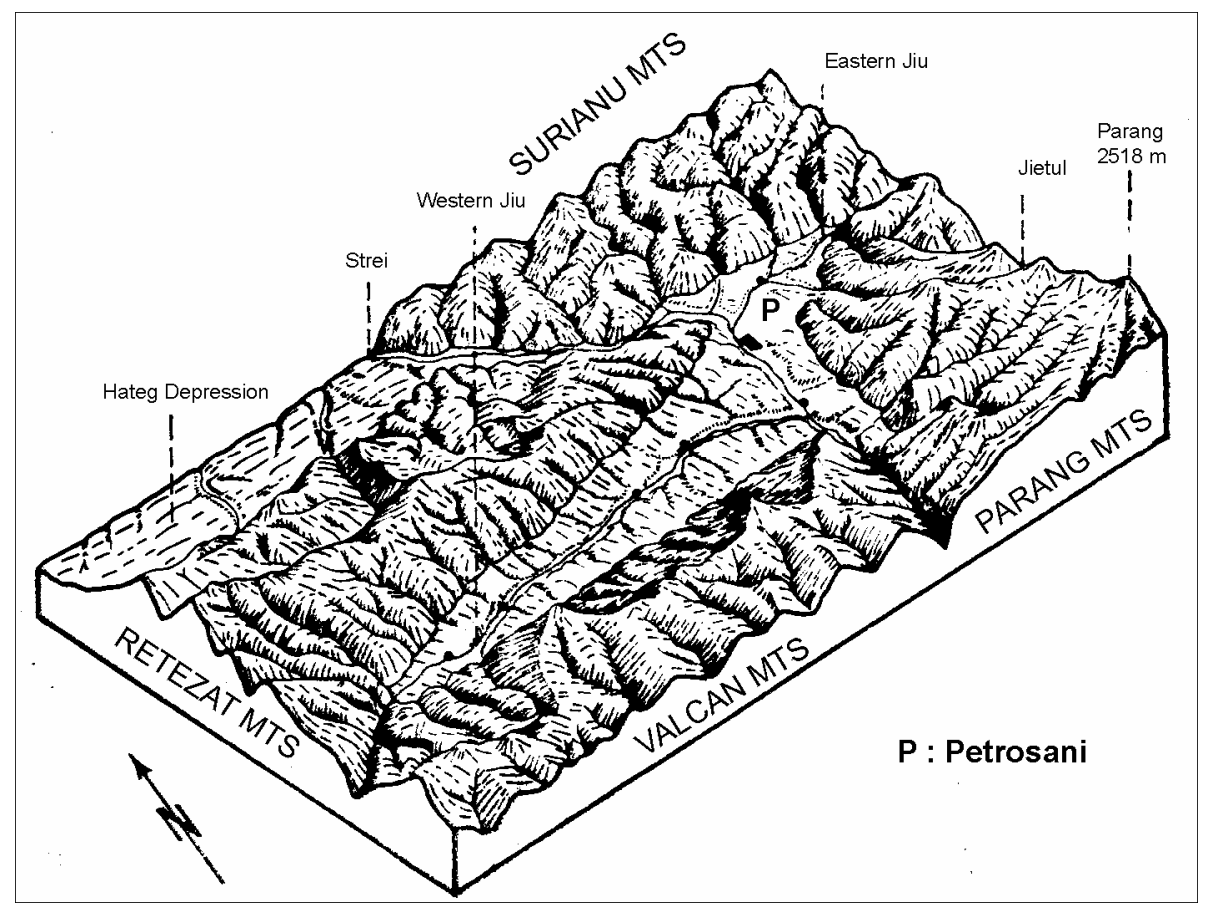

Fig. 1. 3D sketch map of Petroşani Depression (after Pop, 1993; modified)

\section{AIR POLLUTANTS}

The mainspring air pollution is represented by the artificial pollutions, as transports or various technological processes. Combustion processes used for generating electricity or thermal or mechanic energy for industry, home heating or the engine running represent another main pollution source (Moris \& Therivel, 1996).

The coal, petroleum or its derivates and natural gas represent the principal energy sources. Both coal and oil putout at burning wide quantities of pollutant products, their bulk depending on the quality of the burning process ant the fuel purity.

From a theoretic point of view, an ideal pure fuel, at a complete burning should eliminates only carbon dioxide and water, eventually with some traces of azoth oxides derivate trough the reactions with the atmospheric azoth. 
Practical, to these burning products, a mixture of gas and suspensions in very variable concentrations that compose the smoke and the vent gas, is always added. The gas components are represented, forth the carbon dioxide and azoth oxides, by sulphur dioxide, carbon oxide, hydrocarbons, aldehydes. The suspension components involved are among ash particles of mineral origin, unburned coal with high values of volatile components, grime. The suspension components, mainly the coal particles have a large absorbent capacity, retaining the gas that compose the smoke and generating condensing nucleus for the high temperature evaporation substances. This mixture is diffusing into the atmosphere, generating different concentrations of these components. The fuel nature play an extreme important role concerning the composition and concentration of the pollution products resulted from burning, the coal representing for instance the main source for the industry and house heating energies. If the coal is inferior, the quantity of pollutants resulted is bigger. The coal burning generates also by pyrolithic and distillation processes, a series of aromatic hydrocarbons, some of them with cancerous effects, like 3,4 - bensiprene. A higher ash coal content, induces a higher quantity of minerals in suspension and the $\mathrm{SO}_{2}$ content depends directly on the natural sulphur bulk contained. Similarly, the hydrocarbon content is high.

The natural gas burning is less harmfulness if considering the atmosphere pollution, because the products resulted from the burning are in small quantities and generating less suspension products. The carbon oxide resulted through an incomplete burning is more a harmful factor for the intramural spaces and less for the external ones. The azoth oxides represent the main gas pollutant of this fuel. Cancer dangerous policyclic aromatic hydrocarbons were evidence in the smoke resulted through the natural gas burning, but in more moderate concentrations if compared with the ones of the coal or petroleum burning.

Transports. The cars are the main polluting factors, because of their increased number and the high quantity of polluting substances liberated through their combustion. Among these substances the most important are hydrocarbons, including the policyclic aromatic ones, the carbon oxide, the azoth oxides and the lead. The last one, present as lead tetraethyl into the gas used by the cars that work with high octane value gasoline, is eliminates through the vent gas as a mineral lead, a more and more notably factor.

The hydrocarbons resulted through the gas burning into the internal-combustion engines give rise to the oxidant substances that are generating due the photochemical processes under the action of the solar radiations, by the reaction produced between these hydrocarbons, the azoth oxides and the oxygen form the atmosphere. This kind of pollution is characteristic for the settlements with heavy traffic and considerable number of sunny days, resulting through the so-called photochemical oxide pollution. In towns from temperate climate realm is dominating the pollution due to the smoke resulted by the industrial and home heating fuel combustions. The suspensions, azoth oxides and sulphur dioxide are dominating.

The railroad waggonage or the waterage can contribute to the air pollution in certain localities, also due to the fuel combustion necessary for producing energy. Compared to road transports, the railroad ones are much less polluting.

For instance, the airlift air pollution does not raise notable health problems. 


\section{THE EVOLUTION OF POLLUTANTS INTO THE ATMOSPHERE}

The term "photochemical oxidant" is related to any atmospheric substance produced in a photochemical process, able to oxidize any material still incomplete air oxidized. These are secondary pollutants that appear due to the interactions of the primary pollutants under the light action, which generation and action are favored by various factors.

The participation of the azoth dioxide photolitic cycle to the generating process of the photochemical oxidants is now completely clarified. Two of the stronger secondary pollutants that result due the participation of the hydrocarbons to this cycle are identified. These two secondary pollutants are the ozone and the peroxiacethyle nitrite $\left(\mathrm{CH}_{3}-\mathrm{CO}-\mathrm{O}-\mathrm{O}-\mathrm{NO}_{2}\right)$, the simpler member of a group of compounds - the peroxiacetyl nitrites-, usually called PAN. Whereas in atmosphere there are producing also other photochemical oxidants, we will refer further to these two ones, because they are very resembling with the others.

The presence of the hydrocarbons into the atmosphere, mainly of the methane resulted from natural processes, in well known. The basic hydrocarbon concentrations in the air outside the large towns is around 1.0-1.5 ppm for the methane and less than $0.1 \mathrm{ppm}$ for each of the others hydrocarbons. It results from natural sources, biologic and geothermal processes, coal, and petroleum or gas fields.

As the case stand for other pollutants, the transport is the major source that contributes with more than $50 \%$ at the hydrocarbon emissions. Gasoline engines are the most representatives. The gasoline evaporation and the unburned fuel emission in the vent gas are the two processes responsible for the air pollution made by vehicles.

The industry is another source of hydrocarbon pollution. Hydrocarbons are losing into the atmosphere during their fabrication, stocking and transport. The organic solvents composing the lacquers and paints have hydrocarbon contents between $40-80 \%$. Their evaporations contribute around $10 \%$ to the total industrial emissions.

The different hydrocarbons present into the atmosphere have a large spectrum of tendencies to enter in the air polluting photochemical process. As a consequence it is impossible to predict exactly the contribution of a hydrocarbon mixture to the air pollution.

The generating speeds as well as the oxidizer concentrations are related to the light intensity, hydrocarbon and azoth oxides concentrations and ratios, temperature.

\section{THE CORRELATION BETWEEN THE RAINFALL COMPOSITION AND THE AIR POLLUTION}

In order to study the influence between the rainfall qualities and the air pollution in Jiului Valley, a number of measurements on the air quality and rainfall composition have been done on two sites at Paroşeni. These two sites are situated on opposite directions, if related to the thermoelectric power plant from Paroşeni, at Livezeni and Valea de Peşti.

The results of this experiment are particularized in the Table 1.

The values from the table indicate that the $\mathrm{SO}_{2}$ and $\mathrm{NO}_{2}$ concentrations are greater in the closeness of the Paroşeni thermoelectric power plant that constitutes the mainspring of the air pollution from this area. 
$\mathrm{SO}_{2}$ and $\mathrm{NO}_{2}$ concentrations in the air at Jiului Valley

Table 1.

\begin{tabular}{|c|c|c|c|c|c|c|}
\hline \multirow{2}{*}{ Component } & \multirow{2}{*}{ Site } & \multicolumn{5}{|c|}{ Month } \\
\cline { 3 - 7 } & & January & February & March & April & Mai \\
\hline \multirow{2}{*}{$\mathrm{SO}_{2}$} & Livezeni & 0,008 & 0,009 & 0,006 & 0,005 & 0,008 \\
\cline { 2 - 7 } & Paroşeni & 0,012 & 0,010 & 0,011 & 0,009 & 0,010 \\
\hline \multirow{2}{*}{$\mathrm{NO}_{2}$} & Livezeni & 0,006 & 0,004 & 0,007 & 0,008 & 0,005 \\
\cline { 2 - 7 } & Paroşeni & 0,009 & 0,010 & 0,008 & 0,011 & 0,009 \\
\hline
\end{tabular}

The compositions of the rainfall are particularized in the Table 2.

Table 2.

The compositions of the rainfall

\begin{tabular}{|l|c|c|c|}
\hline \multirow{2}{*}{\multicolumn{1}{|c|}{ Parameter }} & \multicolumn{3}{c|}{ Sample site } \\
\cline { 2 - 4 } & Livezeni & Paroşeni & Valea de Peşti \\
\hline pH & 6,79 & 6,72 & 7,39 \\
\hline Conductivity & 82,5 & 81,6 & 181,5 \\
\hline Alkalinity & 0,74 & 0,72 & 1,34 \\
\hline $\mathrm{Cl}^{-}$ & 2,8 & 2,91 & 4,9 \\
\hline $\mathrm{SO}_{4}{ }^{2-}$ & 11,47 & 9,78 & 43,93 \\
\hline $\mathrm{NO}_{3}{ }^{-}$ & 0,0046 & 0,01 & 0,0032 \\
\hline $\mathrm{NO}_{2}^{-}$ & 0 & 0,007 & 0 \\
\hline $\mathrm{Ca}^{2+}$ & 6,61 & 11,58 & 28,85 \\
\hline $\mathrm{Mg}^{2+}$ & 10,67 & 1,09 & 3,41 \\
\hline $\mathrm{Na}^{+}$ & 0,93 & 0,098 & 1,19 \\
\hline $\mathrm{K}^{+}$ & 5,15 & 0,55 & 3,12 \\
\hline $\mathrm{NH}_{4}{ }^{+}$ & 0,1 & 0,198 & 0,39 \\
\hline Degré de dureté & 4,26 & 1,85 & 4,82 \\
\hline
\end{tabular}

The Table 2 data allow a series of very interesting conclusions that complete the Table 1 information's. Expectedly, the rainfall from Valea de Peşti has a large content of dissolved substances at the site located on the main's area wind direction.

The rainfall $\mathrm{pH}$ has a greater value at Valea de Peşti, in spite of the expected acid rains that should have to occur there. The explanation consists in the high content of $\mathrm{Ca}$ ions, resulted from the suspension dust spread by the thermoelectric power plant that neutralized the sulphuric acid resulted through the $\mathrm{SO}_{2}$ oxidation.

The concentration of the azothite and azothate reflect very well the photochemical processes that develop into the air. The azotite ions occur at Paroşeni only, where the azoth monoxide is dominating. Because it is progressively oxidizing to azoth dioxide, at larger distances the concentration of this ion into rainfall is substantially reduced.

Operating the data resulted on different periods, one can observes that in the sunniest intervals the azotate ions concentration is greater in water due to a more intensive photochemical processes (Table 3). These data offer valuable information concerning the azoth monoxide and dioxide concentrations into the air. 
Table 3.

The evolution of azothite and azothate ions into the rainfall (2002).

\begin{tabular}{|l|c|c|c|c|c|c|}
\hline \multirow{2}{*}{ Site } & Compo- & \multicolumn{5}{|c|}{ Month } \\
\cline { 3 - 7 } & nent & April & August & September & October & November \\
\hline Livezeni & $\mathrm{NO}_{2}^{-}$ & 0,0113 & 0,0000 & 0,005 & 0,006 & 0,037 \\
\hline & $\mathrm{NO}_{3}^{-}$ & 0,0313 & 0,0046 & 0,0108 & 0,009 & 0,015 \\
\hline Paroşeni & $\mathrm{NO}_{2}^{-}$ & & & & 0,007 & \\
\hline & $\mathrm{NO}_{3}^{-}$ & & & & 0,010 & \\
\hline $\begin{array}{l}\text { Valea } \\
\text { de Peşti }\end{array}$ & $\mathrm{NO}_{2}^{-}$ & & 0,0000 & & & \\
\hline & $\mathrm{NO}_{3}^{-}$ & & 0,0032 & & & \\
\hline
\end{tabular}

The higher $\mathrm{K}$ and $\mathrm{Mg}$ ions' concentrations in the Jiului Valley Eastern side can be related with the area dominating feldspath potassique that reach into the air as dusts partially dissolute by the rainfall, consequence of photochemical reactions.

\section{CONCLUSIONS}

The rainfall dissolve the products resulted by consequence of the air pollution, as well as the products resulted by the photochemical oxidation.

The azotate and azothite ion's concentrations into the water, offer valuable information concerning the monoxide and dioxide azoth concentrations into the air.

The presence of the cations into the rainfall is due to the emissions of the suspension dusts as a consequence of the industry activities, but also to the dust spread by the winds in the unsettled areas.

\section{REFERENCES}

MOISESCU V., 1980, Considerații asupra unităților litostratigrafice ale Terțiarului din Bazinul Petroşani. Studii şi cercetări de Geologie, Geofizică, Geografie, Geologie, 25, p. 109117, Bucureşti

MORIS P. THERIVEL R., 1996, Methods of Environmental Impact Assessment, p. 120-140, UCL Press, London

POP E. I. 1993, Monografia geologică a Bazinului Petroşani. Editura Academiei Române, 300 p., Bucureşti.

REBRIŞOREANU M., TRAISTĂ E., MATEI A., BARBU O. \& CODREA V., 2002, The impact of the bituminous coal combustion from the thermoelectric power plant from Paroşeni on the environment of Jiu Valley. Studia Universitatis Babeş-Bolyai, Geologia, XLVII, 1, p. 117-126, Cluj-Napoca.

TRAISTĂ E., MADEAR G., 2000, Igiena mediului - Igiena aerului şi a apei, p. 38-43, Editura Universitas Petroşani 